\title{
KelayaKan Sistem EVAKUASI KaWASAN RaWAN BENCANa LETUSAN GUNUNG MERAPI DI KABUPATEN SLEMAN
}

\author{
Dicky Setya Adi W, Kusumastuti, Isti Andini \\ Program Studi Perencanaan Wilayah dan Kota, \\ Fakultas Teknik \\ Universitas Sebelas Maret, Surakarta \\ email : adheweebowo@gmail.com
}

\begin{abstract}
$\overline{\text { Abstract: Evacuation system in Mount Merapi eruption area consist of evacuation component, }}$ such early warning system, meeting point, evacuation lane, evacuation route, barrack, communication and transportation. The role of the goverment is to give services for refugees who live in scenario evacuation area. But there are some constrains, for example damaged road, evacuation lane crossover the bridge, people don't heard the early warning system and high density of barracks. Based on those phenomenons, this research objected is to measure the feasibility of Mount Merapi evacuation system in Sleman district by using qualitative and quantitative method. The results of this research, some of evacuation systems don't have perfect score. Early warning system has score 49\%, meeting point score 96,2\%, evacuation lane $88,7 \%$, evacuation route $100 \%$, barracks $60,7 \%$, transportation and communication $51,8 \%$. From that components, the average score is $75 \%$ which means the system of evacuation in Mount Merapi Eruption Area not feasible yet.
\end{abstract}

Keywords: feasibility, region of infrastructure, evacuation system in mount merapi

\section{PENDAHULUAN}

Secara Geografis Kabupaten Sleman terletak diantara $110^{0} 33^{\prime} 00^{\prime \prime}$ sampai dengan $110^{0} 33^{\prime} 00^{\prime \prime}$ dan mulai $7^{0} 34^{\prime} 51^{\prime \prime}$ sampai dengan 7047'03" Lintang Selatan. Wilayah Kabupaten Sleman sebelah utara berbatasan dengan Kabupaten Boyolali, Provinsi Jawa Tengah, sebelah timur berbatasan dengan Kabupaten Klaten, Provinsi Jawa Tengah dan Kabupaten Magelang, Propinsi Jawa Tengah dan sebelah selatan berbatasan dengan Kota Yogyakarta, Kabupaten Bantul dan Kabupaten Gunung Kidul, Daerah Istimewa Yogyakarta. Secara geografis Kabupaten Sleman merupakan bagian dari Gunung Merapi, sehingga Kabupaten Sleman merupakan bagian KRB Gunung Merapi.

Bahaya di KRB yang diakibatkan oleh erupsi Gunung Merapi memang tidak bisa dihindari, karena bisa datang sewaktu-waktu dan tidak bisa diprediksi, namun bisa diminimalisir dampak yang diakibatkan. Sikap antisipasi dan perencanaan yang matang dalam bencana sangat diperlukan demi keberlangsungan kehidupan yang ada. Gunung Merapi memiliki periode letusan yang terjadi secara teratur, yaitu 2 hingga 5 tahunan serta 7 tahunan dan letusan terakhir Gunung Merapi terjadi pada tahun 2010 yang menghancurkan kawasan di sekitarnya. Bencana ini merupakan yang terbesar dibandingkan dengan bencana serupa dalam lima periode waktu sebelumnya yakni tahun 1994, 1997, 1998, 2001, dan 2006.

Kabupaten Sleman memiliki konsep mitigasi bencana khususnya pada KRB Gunung Merapi. Mitigasi Bencana dapat dalam konteks penataan ruang dapat diartikan suatu alat untuk mencegah/ menghindari/ menghilangkan bahaya, mengurangi tingkat kerentanan, dan meningkatkan ketahanan dari suatu wilayah/ kawasan tertentu. Pendekatan berbasis mitigasi dan pengurangan resiko bencana yang dapat dilakukan adalah dengan (sistem) evakuasi bencana pada saat terjadi erupsi Gunung Merapi. Terdapat dua solusi untuk mengurangi jumlah korban erupasi Gunung Api, salah satunya mengevakuasi penduduk di daerah bahaya (Baxter, etal, 1998). Evakuasi adalah solusi radikal untuk melindungi kehidupan manusia yang mungkin tidak selalu dilakukan dalam kondisi yang menguntungkan dan dapat menyebabkan konsekuensi negatif jika tidak dipersiapkan dengan baik. Namun demikian, evakuasi merupakan cara yang paling efektif untuk mengurangi jumlah korban .

Sistem menurut KBBI adalah perangkat unsur yang secara teratur saling berkaitan sehingga membentuk suatu totalitas. Melihat dari sistem evakuasi Ema (2005) dan Blong (1984) yang 
diimplementasikan pada konsep sistem evakuasi bencana letusan Gunung Merapi di Kabupaten Sleman dibagi menjadi lima komponen, yaitu sistem peringatan dini (early warning system), titik kumpul, jalur evakuasi, rute evakuasi, komunikasi dan transportasi, serta penampungan/ barak pengungsian. Komponen-komponen evakusi tersebut berjalan linier sehingga membentuk sistem evakuasi. Sistem evakuasi letusan Gunung Merapi saat terjadi proses evakuasi bencana pada teknis operasionalnya dibagi berdasarkan sungai-sungai berhulu di lereng Gunung Merapi yang ada di KRB guna menghindari bahaya lahar melewati aliran sungai. Wilayah yang berada di antara dua aliran sungai berhulu di lereng Gunung Merapi tersebut disebut oleh BPBD Kabupaten Sleman sebagai sektor evakuasi bencana letusan Gunung Merapi. Bisa dikatakan pada satu sektor memiliki subsistem evakuasi bencana letusan Gunung Merapi. Terdapat lima sektor yang berada di KRB Gunung Merapi Kabupaten Sleman, yaitu sektor A, sektor B, sektor C, sektor D, dan sektor E. Masing-masing subsistem berjalan secara bersamaan sesuai dengan skenario evakuasi masing-masing sektor saat status Gunung Merapi menjadi waspada.

Pada tahun 2014 pernah terjadi letusan freatik, masyarakat KRB khususnya Desa Hargobinangun langsung melakukan evakuasi dengan sistem evakuasi letusan Gunung Merapi tahun 2014. Kondisi jalanjalan evakuasi beberapa ruas mengalami kerusakan karena kegiatan normalisasi Sungai Gendol, berupa jalan lokal yang berada di Kecamatan Cangkringan. Jalan yang mengalami kerusakan di jalan yang berada dalam dusun digunakan untuk akses menuju titik kumpul dan jalan lokal yang mengalami kerusakan digunakan untuk jalur evakuasi dari titik kumpul menuju barak pengungsian. Selain itu, sebagian masyarakat KRB merasakan tidak mendengarkan bunyi sirine sistem peringatan dini / early warning system yang sampai ke dusun mereka. Sebagian masyarakat KRB yang berada di Kecamatan Cangkringan merasa bahaya karena jalur evakuasi melewati jembatan sungai memotong Sungai Kuning yang biasa menjadi aliran lahar panas maupun dingin. Pada sistem evakuasi bencana letusan Gunung Merapi 2014 hendaknya dapat memberikan kenyamanan, keselamatan dan keberlanjutan kehidupan di Kawasan Rawan Bencana Gunung Merapi. Maka penelitian ini dibuat untuk melihat kelayakan sistem evakuasi bencana letusan Gunung Merapi tahun 2014.

Tujuan yang ingin dicapai dalam penelitian ini adalah mengidentifikasi kelayakan sistem evakuasi bencana letusan Gunung Merapi.

\section{METODE}

A. Ruang Lingkup

Lokasi Penelitian berada pada KRB Gunung Merapi di Kabupaten Sleman. Wilayah penelitian merupakan Kawasan Rawan Bencana Letusan Gunung Merapi yang masuk ke dalam skenario evakuasi bencana letusan Pemerintah Kabupaten Sleman. Wilayah tersebut merupakan lima Kecamatan yang berada di lereng Gunung Merapi Kecamatan Tempel, Kecamatan Turi, Kecamatan Pakem, Kecamatan Cangkringan, dan Kecamatan Ngemplak.

Pembatasan materi penelitian dilakukan pada ruang lingkup substansi berdasarkan pada sasaran yang telah ditetapkan di atas, akan didapatkan suatu batasan penelitian yang berfungsi agar penelitian tidak lepas dari tema dan judul yang diangkat. Batasan materi pada penelitian ini adalah mengidentifikasi kelayakan sistem evakuasi bencana letusan Gunung Merapi.

B. Metode Analisis

Penelitian ini menggunakan metode analisis kapasitas yang mengetahui sebuah fungsi pelayanan. Fungsi pelayanan memberikan indikasi kualitas dan tingkat ketercukupan pelayanan, sehingga semakin baik fungsi pelayanan, kualitas fasilitas juga semakin baik. Sedangkan jika memiliki standart pelayanan minimal tertentu, maka kondisi fungsi pelayanan lebih baik jika nilainya melebihi standart (Lutfi Muta'ali, 2015). Fungsi pelayanan dikatakan baik bila sama dengan standart maupun melebihi standart. Analisis selanjutnya adalah analisis kelayakan. Ditotal skor dari komponen- 
komponen evakuasi, bila hasil ratarata dari keseluruhan skor sama dengan standart pelayanan yaitu $100 \%$, maka sistem evakuasi dikatakan layak.

\section{HASIL DAN PEMBAHASAN}

A. Analisis Kapasitas Komponen sistem evakuasi Kawasan Rawan Bencana Gunung Merapi di Kabupaten Sleman

1. Kapasitas sistem peringatan dini (early warning system), dengan analisis GIS, dengan buffering dapat dilihat dalam Lampiran 1.

a. Sektor A

Dengan analisis menggunakan GIS, dengan buffering, jangkauan sirine sistem peringatan dini untuk Desa Merdikorejo persentase kapasitas $0 \%, \quad$ Desa Wonokerto persentase kapasitas 0\%, Desa Girikerto $42 \%$, Desa Pondokrejo kapasitas $0 \%$, Desa Banyurejo 0\%, Desa Lumbungrejo 0\%, dan Desa Sumbungrejo 0\%.

b. Sektor B

Dengan analisis menggunakan GIS, dengan buffering, jangkauan sirine sistem peringatan dini untuk Desa Candibinangun 57\%, Desa Pakembinangun 0\%, Desa Hargobinangun 84\%, Desa Umbulharjo 9\%.

c. Sektor C

Dengan analisis menggunakan GIS, dengan buffering, jangkauan sirine sistem peringatan dini untuk Desa Umbulharjo persentase kapasitas $69 \%$, Desa Wukirsari persentase kapasitas 43\%, Desa Widodomartani persentase kapasitas 14\%, Desa Bimomartani persentase kapasitas 93\%.

d. Sektor D

Dengan analisis menggunakan GIS, dengan buffering, jangkauan sirine sistem peringatan dini untuk Desa Merdikorejo persentase kapasitas untuk sebagian Desa Kepuharjo persentase kapasitas 100\%, Desa Kepuharjo persentase kapasitas 100\%, sebagian Sindumartani persentase kapasitas sebesar $100 \%$.

e. Sektor A

Dengan analisis menggunakan GIS, dengan buffering, jangkauan sirine sistem peringatan dini untuk Desa Merdikorejo persentase kapasitas 0\%, Desa Wonokerto persentase kapasitas 0\%, Desa Girikerto $42 \%$, Desa Pondokrejo kapasitas $\quad 0 \%$ Desa Banyurejo 0\%, Desa Lumbungrejo 0\%, dan Desa Sumbungrejo 0\%.

2. Kapasitas titik kumpul

a. Sektor A

Kapasitas kepemilikan titik kumpul, untuk Desa Girikerto, Desa Purwobinangun, Desa Wonokerto, Desa Pondokrejo persentase kapasitas 100\%, Desa Purwobinangun persentase kapasitas $85,7 \%$, Desa Wonokerto 25\%, dan Desa Merdikorejo persentase kapasitas 100\%.

b. Sektor B

Kapasitas kepemilikan titik kumpul, untuk Desa Hargobinangun $100 \%$.

c. Sektor C

Kapasitas kepemilikan titik kumpul, untuk Desa Umbulharjo persentase kapasitas 100\%, Desa Wukirsari persentase kapasitas 100\%.

d. Sektor D

Kapasitas kepemilikan titik kumpul, untuk Desa Kepuharjo, Desa Wukirsari, Desa Argomulyo persentase kapasitas 100\%.

e. Sektor D 
Kapasitas kepemilikan titik kumpul, untuk Desa Glagaharjo, Desa Argomulyo persentase kapasitas $100 \%$.

3. Kapasitas Jalur Evakuasi Jalur evakuasi terbagi menjadi dua sub variabel, yaitu keamanan jalur evakuasi dan kelancaran jalur evakuasi

a. Kapasitas keamanan jalur evakuasi

Kapaitas keamanan jalur terbagi menjadi dua, yaitu keamanan jalur evakuasi dari bahaya potensi luapan lahar melewati sungai dan keamanan jalur melewati jembatan sungai. Kapasitas jalur aman dari bahaya potensi lahar melewai sungai dengan buffering GIS, dapat dilihat dalam Lampiran 2 .

Sektor A, persentase kapasitas jalur yang aman dari bahaya potensi lahar melewati sungai $94,6 \%$. Sektor B, persentase kapasitas jalur yang aman dari bahaya potensi lahar melewati sungai 97,4\%, Sektor C, persentase kapasitas jalur yang aman dari bahaya potensi lahar melewati sungai $98,5 \%$, Sektor D, persentase kapasitas jalur yang aman dari bahaya potensi lahar melewati sungai 96,2\%. Sektor E, $100 \%$. Kemudian sektor A, sektor B, sektor C persentase kapasitas jalur yang aman dari perpotongan jalur dengan jembatan sungai $100 \%$. Sektor D, persentase kapasitas jalur yang aman dari perpotongan jalur dengan jembatan sungai 72\%. Sektor E, persentase kapasitas jalur yang aman dari perpotongan jalur dengan jembatan sungai $100 \%$.

b. Kapasitas kelancaran jalur evakuasi terbagi menjadi dua sub variabel, yaitu jalur evakuasi bisa bersimpangan dua truk evakuasi dan jalur evakuasi dalam kondisi rata beraspal. Sektor A, persentase kapasitas jalur evakuasi bisa bersimpangan dua truk evakuasi 53\%, Sektor B, persentase kapasitas jalur evakuasi bisa bersimpangan dua truk evakuasi $65 \%$. Sektor C, persentase kapasitas jalur evakuasi bisa bersimpangan dua truk evakuasi 95\%. Sektor D, persentase kapasitas jalur evakuasi bisa bersimpangan dua truk evakuasi 64\%. Sektor E, 95\%. Kemudian sektor A, persentase kapasitas kondisi jalur rata beraspal $100 \%$. Sektor B, persentase kapasitas kondisi jalur rata beraspal $100 \%$. Sektor C, persentase kapasitas kondisi jalur rata beraspal $100 \%$. Sektor D, persentase kapasitas kondisi jalur rata beraspal $78,5 \%$. Serta sektor E, persentase kapasitas kondisi jalur rata beraspal $66,7 \%$.

4. Kapasitas Rute Evakuasi

Kapasitas rute evakuasi dilihat berdasarkan adanya penanda rute evakuasi dari titik kumpul menuju barak pengungsian. Sektor A, sektor B, sektor C, sektor D, sektor E persentase kapasitas rute evakuasi $100 \%$.

5. Kapasitas Komunikasi dan Transportasi Evakuasi

Kapasitas Komunikasi evakuasi dilihat dari adanya alat komunikasi handy talky. Sektor A, persentase kapasitas komunikasi evakuasi $100 \%$. Sektor B, persentase kapasitas komunikasi evakuasi $100 \%$. Sektor C, persentase kapasitas komunikasi evakuasi $100 \%$. Sektor D, persentase kapasitas evakuasi $100 \%$. Sektor E, 
persentase kapasitas evakuasi

100\%. Kapasitas moda transportasi dilihat dari adanya moda transportasi. Sektor A, persentase kapasitas moda transportasi 4\%. Sektor B, persentase kapasitas moda transportasi 3\%. Sektor C, persentase kapasitas moda transportasi 3\%. Sektor D, persentase kapasitas moda transportasi 3\%. Sektor E, persentase kapasitas moda transportasi 5\%.

6. Kapasitas Barak Pengungsian

Kapasitas barak pengungsian terbagi menjadi dua, yaitu kapasitas daya tampung barak pengungsian dan kapasitas sarana prasarana barak pengungsian.

a. Sektor A

Persentase kapasitas Barak Girikerto 20\%, Barak Purwobinangun 21\%, Barak Wonokerto 29\%. Persentase barak Barak Pondokrejo 9\%. Barak Alternatif (PBPTH Yogyakarta, BLK Sleman) 28\%. Persentase kapasitas Barak Lumbungrejo 64\%. Persentase kapasitas Barak Merdikorejo 5\%.

b. Sektor B

Persentase kapasitas Barak Hargobinangun $\quad 15 \%$. Persentase kapasitas Barak Shelter ACT Gondanglegi $16 \%$. Persentase kapasitas Barak UII 19\%.

c. Sektor C

Persentase kapasitas daya tampung Barak Brayut 20\%. Persentase kapasitas daya tampung Barak Plosokerep 17\%. Persentase kapasitas daya tampung Barak Umbulmartani $10 \%$.

d. Sektor D

Persentase kapasitas daya tampung Barak Kiyaran dan Wukirsari $37 \%$. Persentase kapasitas daya tampung Barak Barak Kuwang 8\%.
Persentase kapasitas daya tampung Barak $13 \%$.

e. Sektor E

Persentase kapasitas daya tampung Barak Glagaharjo $16 \%$. Persentase kapasitas daya tampung Barak Gayam $45 \%$. Persentase kapasitas daya tampung Barak Glagaharjo 16\%. Persentase kapasitas daya tampung Barak Koripan 19\%.

Kapasitas sarana prasarana barak pengungsian. Sektor A, sektor B, sektor C, sektor D, sektor E persentase kapasitas sarana prasarana $100 \%$.

B. Analisis Kelayakan Sistem Evakuasi Kawasan Rawan Bencana Letusan Gunung Merapi

Analisis kelayakan sistem evakuasi kawasan rawan bencana merupakan total skor dari komponen-komponen evakuasi. Jumlah total dari keseluruhan skor komponenkomponen evakuasi berjumlah $825,3 \%$ dengan rata-rata $75 \%$. Skor rata-rata sistem evakuasi masuk ke dalam penilaian tidak layak. Sistem evakuasi terkait infrastruktur Kawasan Rawan Bencana di Kabupaten Sleman dalam keadaan tidak layak.

\section{KESIMPULAN}

Kesimpulan yang didapat dari temuan penelitian dan pembahasan kelayakan sistem evakuasi kawasan rawan bencana letusan Gunung Merapi di Kabupaten Sleman. Kapasitas komponen-komponen evakuasi KRB Gunung Merapi pada keseluruhan sektor, sistem peringatan dini persentase kapasitas 49\%, titik kumpul persentase kapasitas 96,2\%, jalur evakuasi persentase kapasitas $88,7 \%$, rute evakuasi persentase kapasitas $100 \%$, komunikasi dan transportasi persentase kapasitas $51,8 \%$, dan barak pengungsian persentase kapasitas $60,7 \%$. Rata-rata dari keseluruhan skor komponenkomponen evakuasi belum mencapai persentase $100 \%$, maka dikatakan sistem evakuasi KRB Gunung Merapi tidak layak, menurut Ema (2005) dan Blong (1984) kapasitas sistem evakuasi seharusnya bisa 
memenuhi pengungsi, sehingga sistem bisa dikatakan layak.

Rekomendasi untuk pemerintah dalam mewujudkan sistem evakuasi KRB letusan Gunung Merapi yang layak, dengan mewujudkan infrastruktur sistem evakuasi yang memenuhi kapasitas pengungsi. Peneliti mengharapkan adanya penelitian lanjutan pada sistem evakuasi KRB letusan Gunung Merapi ditinjau dari sudut pandang selain kelayakan sistem evakuasi.

\section{REFERENSI}

Baxter, etal, 1998, kesiapsiagaan masyarakat terhadap bahaya banjir lahar panas dan dingin Gunung Merapi, diakses 28 November jam 15.34 http://www.mysciencework.com/publica tion/read/9453135/kesiapsiagaanmasyarakat-terhadap-bahaya-lahardingin-gunung-merapi\#page-null

Blong, 1984."Perencanaan Evakuasi.’'Di dalam Kajian Pembuatan Jalur Evakuasi di Kawasan Rawan Bencana Merapi Kabupaten Sleman, diedit oleh Tim Halaman, 15. Yogyakarta : BPBD Yogyakarta.

Ema, 2005.’Tahap Evakuasi”. Di dalam Kajian Pembuatan Jalur Evakuasi di Kawasan Rawan Bencana Merapi Kabupaten Sleman, diedit oleh Tim Halaman, 14. Yogyakarta : BPBD Yogyakarta.

Muta'ali, Lutfi, 2015. Teknik analisis regional. Yogyakarta : Badan Penerbit Fakultas Geografi UGM 


\section{LAMPIRAN}

Lampiran 1. Peta Jangkauan Early Warning System KRB Gunung Merapi
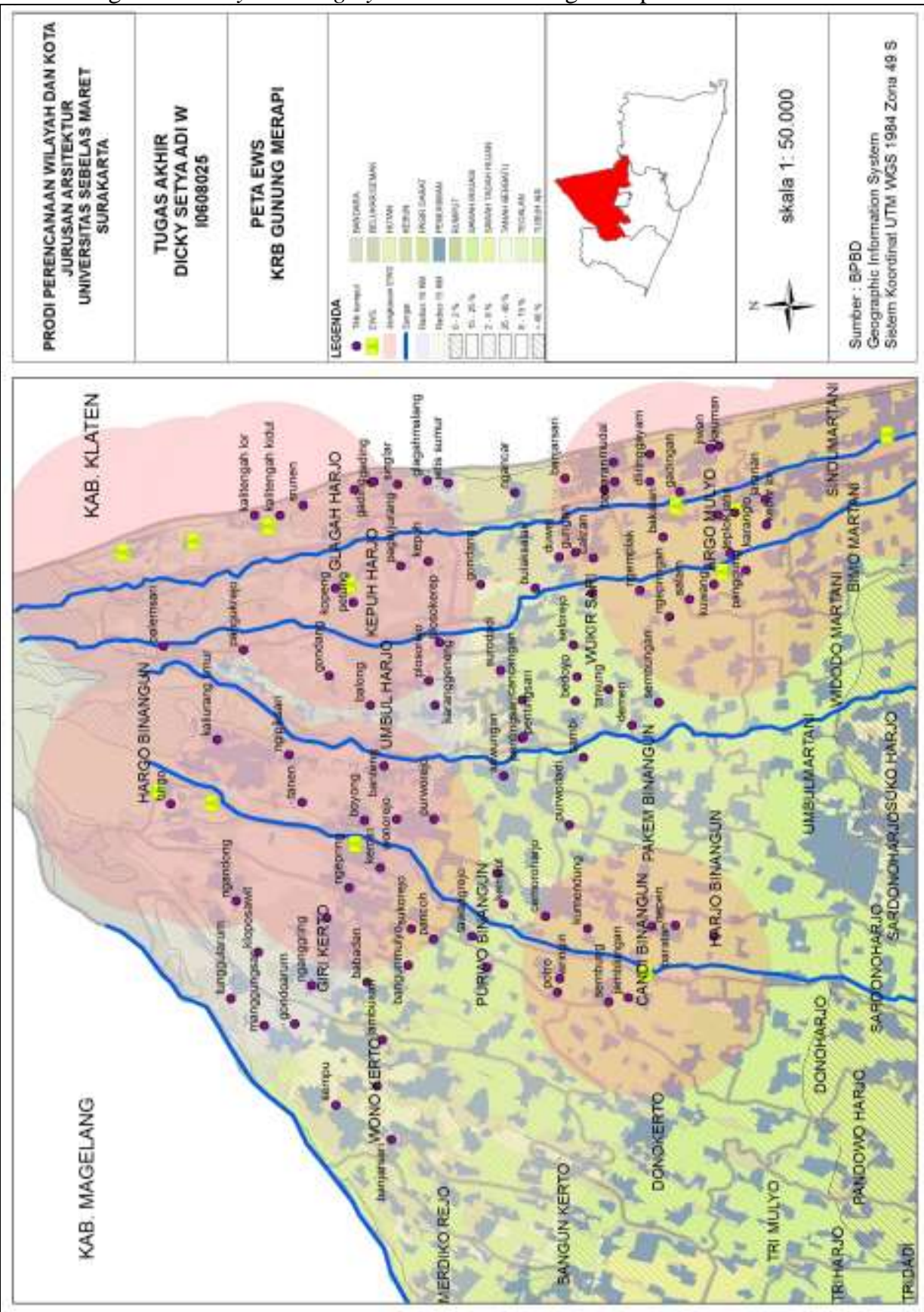
Lampiran 2. Peta Jalur Evakuasi KRB Gunung Merapi
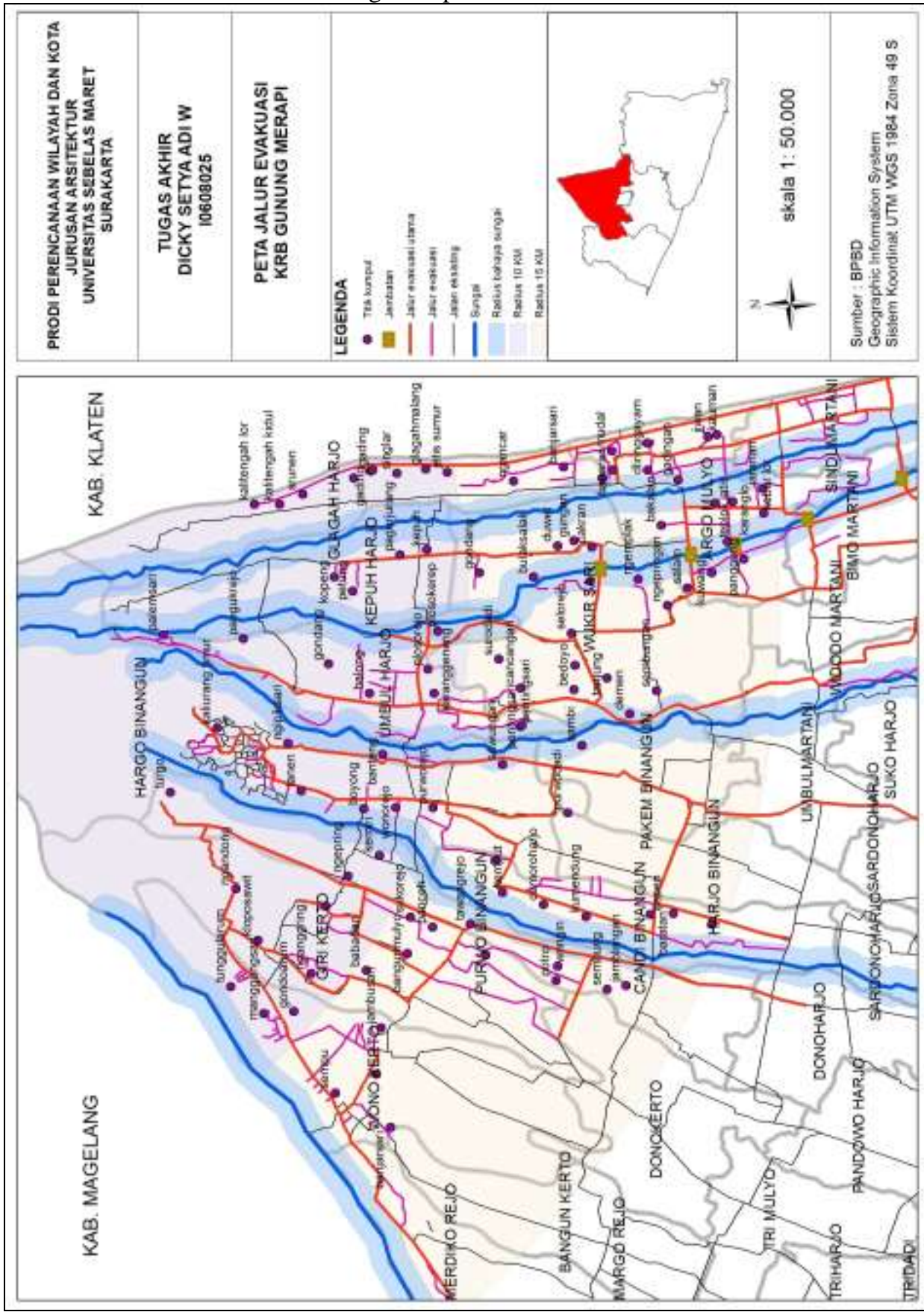